\title{
Methodology of testing common rail fuel injectors with the use of Gauss's formulas
}

The paper presents the methodology of testing common rail fuel injectors, which consisted in extending the standard diagnostic procedures with the analysis of the resulting fuel delivery fields. The calculations were carried out in a popular spreadsheet, using Gauss's formulas (the so-called shoelace formula). In this way, the necessity to modify the test bench software was eliminated, as the analytical process took place after the end of the active experiment phase. It has been shown that the proposed solution should be particularly useful in problematic situations where clear-cut verification and assessment of the technical condition of the fuel injectors is sometimes difficult, as shown in the example. In addition, implementation in a digital environment allows the presented algorithms to be reused in research with a similar profile.

Key words: common rail fuel injectors, extension of diagnostic procedures, Gauss's formulas, resulting fuel delivery fields

\section{Introduction}

In recent years, services related to the regeneration of malfunctioning common rail fuel injectors have become particularly important. Before the repair, a verification process is carried out on the test bench, which allows checking the parameters specified by the manufacturer, including mainly the correctness of fuel delivery. In most cases, standard diagnostic procedures are sufficient to assess the technical condition of the fuel injector, as they relate to critical engine operation points. Depending on the results obtained, maintenance activities may be limited to cleaning (external, internal) and possible adjustment of individual doses, or may require partial or complete disassembly, microscopic inspection and replacement of defective components with new ones [18]. However, there are problematic situations that necessitate the use of extended diagnostics [6,9]. An additional correction is made on the basis of the fuel injection characteristics, implemented with the full spectrum of operating pressures and actuation (opening) times of the fuel injector sprayer [7]. Unfortunately, this function is available only on selected test benches, and the time consumption of the experimental phase, compared to the production procedures, increases several times $[4,16,17]$.

For the above reasons, the own methodology was proposed, in which the base points were located and connected in a Cartesian coordinate system, and then the resulting fuel delivery fields of the tested fuel injector with the reference fuel injector were calculated and compared. To achieve this goal, classic Gauss's formulas, also known as the shoelace formula, were used, implementing a mathematical algorithm in a Microsoft Excel spreadsheet. This approach is convenient from the practical point of view, because it enables a very quick analysis of experimental data that may come from diagnostic tests of fuel injectors of various types or generations.

\section{Methods}

\subsection{Test object}

The tests were carried out on a Delphi DFI 1.2 electromagnetic injector, which was dismantled from the OM 646 engine of a Mercedes-Benz E Class 2.2 CDI vehicle with an operational mileage of 172 thousand kilometres (Fig. 1).

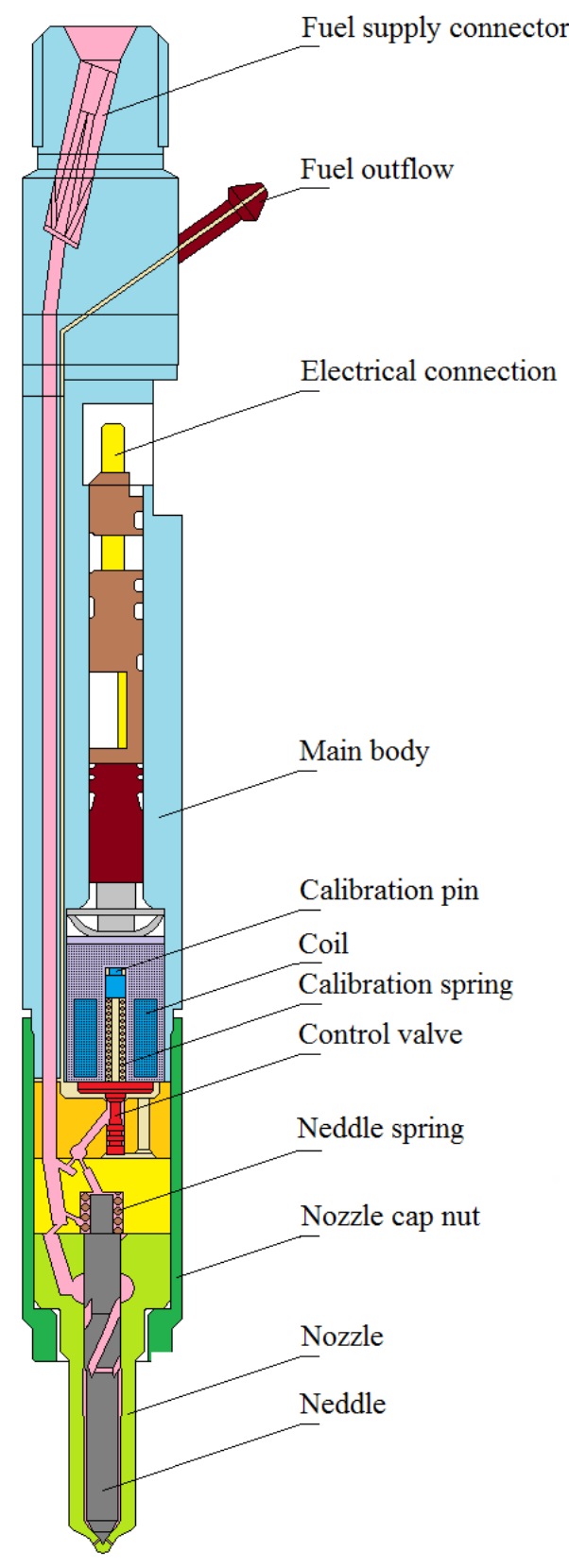

Fig. 1. Delphi fuel injector design 
Fuel injectors of this type operate at fuel injection pressures of up to $140 \mathrm{MPa}$ [14]. A characteristic feature of their structure is the lack of a guide piston acting on the needle, which is activated by a hydraulic system consisting of chambers and a system of channels with neckings [3]. Owing to screw incisions, it partially rotates, increasing the turbulence of the supplied fuel and favouring the selfcleaning of the working surface. Moreover, the lightweight control valve affects a very short fuel injection delay time and a low value of the force needed to move the needle in the sprayer [10]. In the absence of shims, the size of the injected fuel doses depends on the preload of the electromagnetic coil spring, which is determined by the length of the calibration pin [11, 12].

\subsection{Test beds}

The following equipment and instrumentation were used in the regeneration process:

- Zapp CRU 2i test bench (Fig. 2),

- Meiji FL150/70 laboratory microscope,

- ultrasonic baths (Carbon Tech S15/C2, Elmasonic S10H),

- vices and tools for assembling/disassembling the fuel injector.

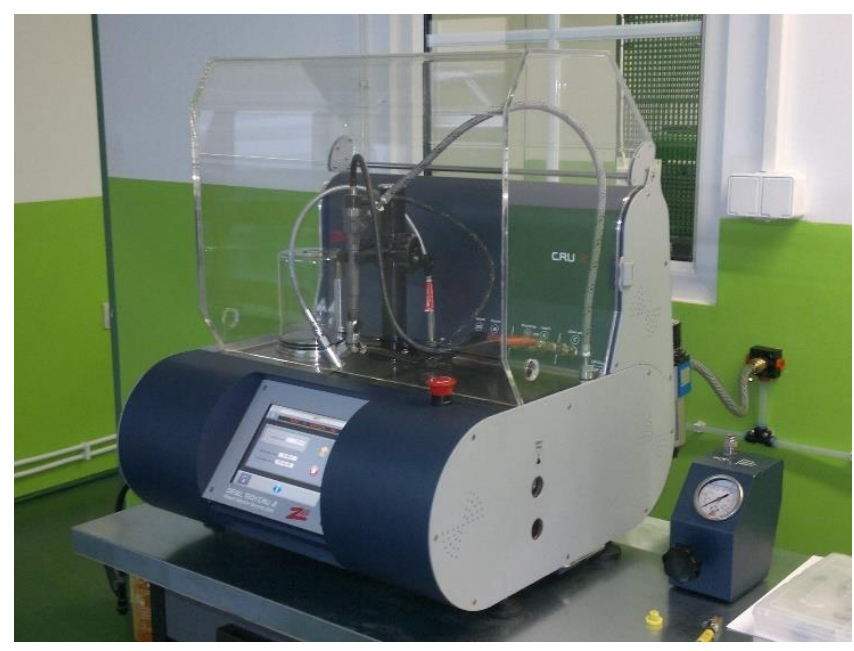

Fig. 2. Zapp CRU 2i test bench

\subsection{Gauss`s formulas}

In the analytical method, the surface area of a polynomial, which is presented in the Cartesian coordinate system, can be calculated on the basis of the contour corner coordinates [1]. On the assumption that the vertices $\left(\mathrm{x}_{1}, \mathrm{y}_{1}\right)$, $\left(\mathrm{x}_{2}, \mathrm{y}_{2}\right), \ldots,\left(\mathrm{x}_{\mathrm{n}}, \mathrm{y}_{\mathrm{n}}\right)$ are marked clockwise, then the area of figure $\mathrm{A}$ is determined using the following formulas $[8,13]$ :

$$
\mathrm{A}=\frac{1}{2}\left|\left(\mathrm{x}_{1} \mathrm{y}_{2}+\mathrm{x}_{2} \mathrm{y}_{3}+\ldots+\mathrm{x}_{\mathrm{n}} \mathrm{y}_{1}\right)-\left(\mathrm{y}_{1} \mathrm{x}_{2}+\mathrm{y}_{2} \mathrm{x}_{3}+\ldots+\mathrm{y}_{\mathrm{n}} \mathrm{x}_{1}\right)\right|
$$

and in a general form for coordinates $\mathrm{x}$

$$
A=\frac{1}{2}\left|\sum_{i=1}^{n} x_{i}\left(y_{i+1}-y_{i-1}\right)\right|
$$

and for coordinates y

$$
A=\frac{1}{2}\left|\sum_{\mathrm{i}=1}^{\mathrm{n}} \mathrm{y}_{\mathrm{i}}\left(\mathrm{x}_{\mathrm{i}-1}-\mathrm{x}_{\mathrm{i}+1}\right)\right|
$$

where:

A - polygon surface area,

$\mathrm{n}-$ number of vertices,

$x_{i}, y_{i}-$ coordinates of the $i-t h$ vertex.

Gauss's formulas should be used jointly as they serve the mutual control of calculations. In order to simplify the analytical procedure, some mathematical operations can be entered into the spreadsheet cells in the form of Table 1.

Table 1. Auxiliary table for the calculation of surface areas

\begin{tabular}{|c|c|c|c|c|}
\hline $\begin{array}{c}\text { Point } \\
\text { number }\end{array}$ & $\mathrm{x}_{\mathrm{i}}$ & $\mathrm{y}_{\mathrm{i}}$ & $\mathrm{x}_{\mathrm{i}+1}-\mathrm{x}_{\mathrm{i}-1}$ & $\mathrm{y}_{\mathrm{i}+1}-\mathrm{y}_{\mathrm{i}-1}$ \\
\hline 1 & $\mathrm{x}_{1}$ & $\mathrm{y}_{1}$ & $\mathrm{x}_{2}-\mathrm{x}_{4}$ & $\mathrm{y}_{2}-\mathrm{y}_{4}$ \\
\hline 2 & $\mathrm{x}_{2}$ & $\mathrm{y}_{2}$ & $\mathrm{x}_{3}-\mathrm{x}_{1}$ & $\mathrm{y}_{3}-\mathrm{y}_{1}$ \\
\hline 3 & $\mathrm{x}_{3}$ & $\mathrm{y}_{3}$ & $\mathrm{x}_{4}-\mathrm{x}_{2}$ & $\mathrm{y}_{4}-\mathrm{y}_{2}$ \\
\hline 4 & $\mathrm{x}_{4}$ & $\mathrm{y}_{4}$ & $\mathrm{x}_{1}-\mathrm{x}_{3}$ & $\mathrm{y}_{1}-\mathrm{y}_{3}$ \\
\hline 1 & $\mathrm{x}_{1}$ & $\mathrm{y}_{1}$ & $\sum_{\mathrm{i}=1}^{\mathrm{n}}\left(\mathrm{x}_{\mathrm{i}+1}-\mathrm{x}_{\mathrm{i}-1}\right)$ & $\sum_{\mathrm{i}=1}^{\mathrm{n}}\left(\mathrm{y}_{\mathrm{i}+1}-\mathrm{y}_{\mathrm{i}-1}\right)$ \\
\hline
\end{tabular}

\section{Analysis results and discussion}

\subsection{Preliminary tests}

Before starting the tests, the fuel injector was thermochemically rinsed on the diagnostic test bench, so it was subjected to the internal cleaning process at an increased temperature of the detergent. This decision was made due to the possibility of the presence of impurities and internal Diesel Injector Deposits (IDIDs), the presence of which adversely affects the method of fuel delivery, reducing the dynamics of the movement of control and actuation ele-

\begin{tabular}{|c|c|c|c|c|}
\hline \multicolumn{3}{|c|}{ Test type } & \multicolumn{2}{|c|}{ Result } \\
\hline \multirow{3}{*}{$\begin{array}{l}\text { Electric test, } \\
\text { eRLC }\end{array}$} & \multicolumn{2}{|c|}{ Coil resistance, $R_{c}[\Omega]$} & \multicolumn{2}{|c|}{$\begin{array}{c}{[0.2-0.6]} \\
\mathbf{0 . 3 8}\end{array}$} \\
\hline & \multicolumn{2}{|c|}{ Coil inductance, $\mathrm{L}[\mu \mathrm{H}]$} & \multicolumn{2}{|c|}{$\begin{array}{c}{[60-110]} \\
76\end{array}$} \\
\hline & \multicolumn{2}{|c|}{ Frequency, f [Hz] } & \multicolumn{2}{|c|}{20} \\
\hline \multicolumn{3}{|c|}{$\begin{array}{l}\text { Reaction speed test, } \\
\text { RSP }[\mu \mathrm{s}]\end{array}$} & \multicolumn{2}{|c|}{$\begin{array}{c}{[300-495]} \\
\mathbf{4 7 8}\end{array}$} \\
\hline \multicolumn{3}{|c|}{$\begin{array}{l}\text { Nozzle opening pressure test, } \\
\text { NOP [MPa] }\end{array}$} & \multicolumn{2}{|c|}{$\begin{array}{c}13-23] \\
\mathbf{1 8} \\
\end{array}$} \\
\hline \multirow{2}{*}{\multicolumn{3}{|c|}{$\begin{array}{l}\text { Leak Test, LKT [MPa] } \\
140 \mathrm{MPa}, 120 \mathrm{~s}\end{array}$}} & $\begin{array}{c}\text { Injection } \\
\text { dosage }\end{array}$ & $\begin{array}{l}\text { Return } \\
\text { dosage }\end{array}$ \\
\hline & & & $\mathbf{0}$ & $\begin{array}{l}{[0-40]} \\
\mathbf{3 4 . 8 6}\end{array}$ \\
\hline \multicolumn{5}{|c|}{$\begin{array}{l}\text { Injector Volume Metering, } \\
\text { IVM }\end{array}$} \\
\hline $\begin{array}{c}\text { Dose } \\
\text { number }\end{array}$ & $\begin{array}{l}\text { Injection } \\
\text { pressure, } \\
\mathrm{p}_{\text {inj }}[\mathrm{MPa}]\end{array}$ & $\begin{array}{c}\text { Nozzle } \\
\text { opening times, } \\
t[\mu \mathrm{s}]\end{array}$ & \multicolumn{2}{|c|}{$\begin{array}{c}\text { Injection } \\
\text { dosage, } \\
\mathrm{d}\left[\mathrm{mm}^{3} / \mathrm{H}\right] \\
\end{array}$} \\
\hline 1 & 40 & 462 & \multicolumn{2}{|c|}{$\begin{array}{c}1.18-7.91] \\
\mathbf{2 . 0 2}\end{array}$} \\
\hline 2 & 80 & 600 & \multicolumn{2}{|c|}{$\begin{array}{c}{[14.43-31.35]} \\
\mathbf{1 6 . 2 4}\end{array}$} \\
\hline 3 & 140 & 700 & \multicolumn{2}{|c|}{$\begin{array}{c}{[31.83-46.33]} \\
\mathbf{4 2 . 4 6}\end{array}$} \\
\hline 4 & 23 & 573 & \multicolumn{2}{|c|}{$\begin{array}{c}0.30-5.55] \\
\mathbf{0 . 5 8}\end{array}$} \\
\hline
\end{tabular}
ments $[2,5,15]$.

Table 2. Results of the preliminary tests on the Zapp CRU 2i stand

The data presented in Table 2 show that the fuel injector passed the standard test procedure, as the obtained results are within the limits permitted by the manufacturer. After installation, however, the engine was characterised by hard, rough operation, particularly at idle and light loads, and the 
service indicator was illuminated on the vehicle's dashboard. For the above reasons, it was decided to implement the proposed methodology.

The results of the IVM volume measurements were located in the Cartesian coordinate system. The connection of the base points 1-2-3-4 made it possible to create an irregular quadrilateral, the surface area of which was estimated using the formulas (2) and (3). For this purpose, calculation formulas were created and entered into the spreadsheet. After substituting the numerical values constituting the vertices of the analysed figure, the resultant fuel metering field was obtained in the preliminary test $A_{\mathrm{PT}}$ (Table 3 ).

Table 3. Calculation of the resultant fuel metering field $\mathrm{A}_{\mathrm{PT}}$

\begin{tabular}{|c|c|c|c|c|}
\hline $\begin{array}{c}\text { Dose } \\
\text { number }\end{array}$ & $\mathrm{t}_{\mathrm{i}}$ & $\mathrm{d}_{\mathrm{i}}$ & $\mathrm{t}_{\mathrm{i}+1-\mathrm{t}_{\mathrm{i}-1}}$ & $\mathrm{~d}_{\mathrm{i}+1}-\mathrm{di}_{-1}$ \\
\hline 1 & 462 & 2.02 & 27 & 15.66 \\
\hline 2 & 600 & 16.24 & 238 & 40.44 \\
\hline 3 & 700 & 42.46 & -27 & -15.66 \\
\hline 4 & 573 & 0.58 & -238 & -40.44 \\
\hline 1 & 462 & 2.02 & $\Sigma=0$ & $\Sigma=0$ \\
\hline \multicolumn{5}{|c|}{$\mathrm{A}_{\mathrm{PT}}$} \\
\hline \multicolumn{5}{|c|}{$\mathbf{1 3 1 7 . 6 0}=1 / 2 \mid(27 \cdot 2.02)+(238 \cdot 16.24)+(-27 \cdot 42.46)+(-238 \cdot 0.58)$} \\
\hline $\mathbf{1 3 1 7 . 6 0}=1 / 2 \mid(15.66 \cdot 462)+(40.44 \cdot 600)+(-15.66 \cdot 700)+(-40.44 \cdot 573)$ \\
\hline
\end{tabular}

The calculations for the reference fuel injector were performed in the same way, using the data provided by the manufacturer (Table 4).

Table 4. Calculation of the resultant fuel metering field $\mathrm{A}_{\mathrm{SI}}$

\begin{tabular}{|c|c|c|c|c|}
\hline $\begin{array}{c}\text { Dose } \\
\text { number }\end{array}$ & $\mathrm{t}_{\mathrm{i}}$ & $\mathrm{d}_{\mathrm{i}}$ & $\mathrm{t}_{\mathrm{i}+1}-\mathrm{t}_{\mathrm{i}-1}$ & $\mathrm{~d}_{\mathrm{i}+1}-\mathrm{di}_{-1}$ \\
\hline $1^{`}$ & 462 & 4.55 & 27 & 19.96 \\
\hline 2 & 600 & 22.89 & 238 & 34.53 \\
\hline 3 & 700 & 39.08 & -27 & -19.96 \\
\hline $4^{`}$ & 573 & 2.93 & -238 & -34.53 \\
\hline $1^{`}$ & 462 & 2.02 & $\Sigma=0$ & $\Sigma=0$ \\
\hline \multicolumn{5}{|c|}{$\mathrm{A}_{\mathrm{SI}}$} \\
\hline \multicolumn{6}{|c|}{$\mathbf{1 9 0 9 . 0 9}=1 / 2 \mid(27 \cdot 4.55)+(238 \cdot 22.89)+(-27 \cdot 39.08)+(-238 \cdot 2.93)$} \\
\hline $\mathbf{1 9 0 9 . 0 9}=1 / 2 \mid(19.96 \cdot 462)+(34.53 \cdot 600)+(-19.96 \cdot 700)+(-34.53 \cdot 573)$ \\
\hline
\end{tabular}

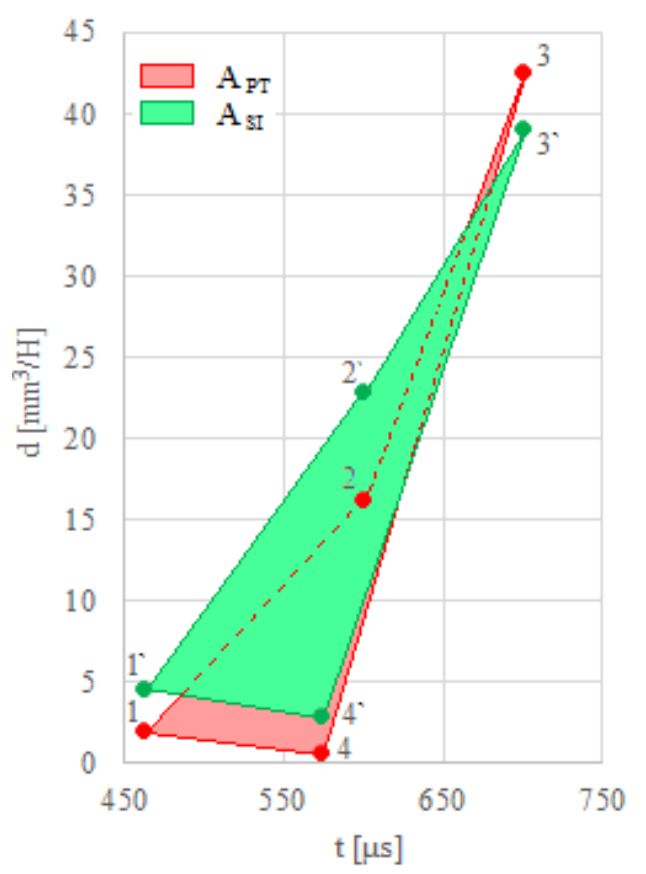

Fig. 3. Graphical interpretation of the preliminary test results
Figure 3 shows the graphic interpretation of the obtained results. The disturbance of the fuel injection process causes a clear shift of the quadrilateral 1-2-3-4, and the position of individual vertices may indicate the cause of the malfunction. The doses obtained at short actuation (opening) times of the sprayer prove that the needle is difficult to lift, which has problems with overcoming the spring tension after applying low operating pressures on the test bench. On the other hand, the discrepancies between points 2-2' and 3-3' suggest incorrect operation of the control valve, in particular the possibility of frictional wear of its guide surface. As a result, the difference between the resulting fuel delivery fields for the tested fuel injector $\mathrm{A}_{\mathrm{PT}}$ and the reference one $\mathrm{A}_{\mathrm{SI}}$ was significant as it amounted to $30.98 \%$.

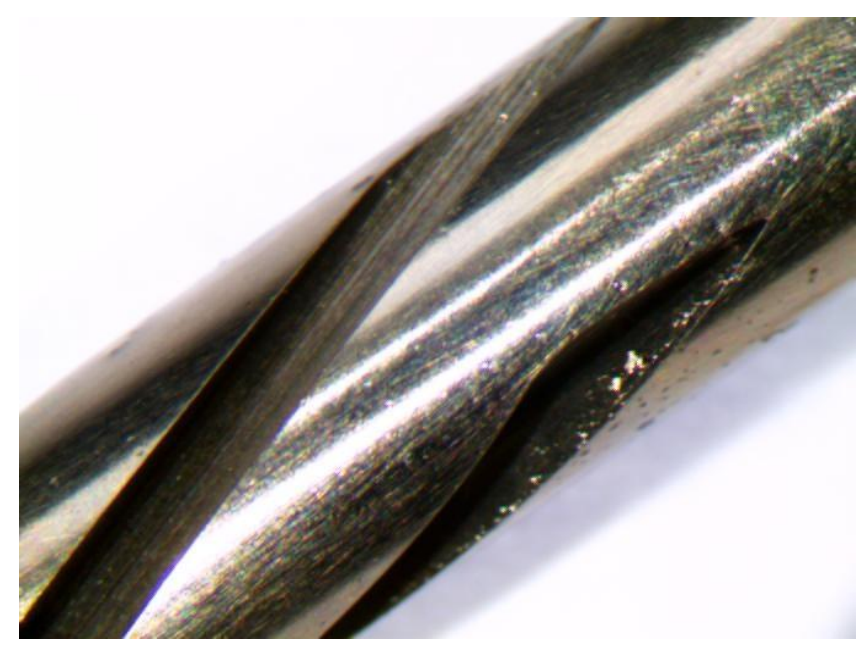

Fig. 4. Longitudinal delineation on the needle

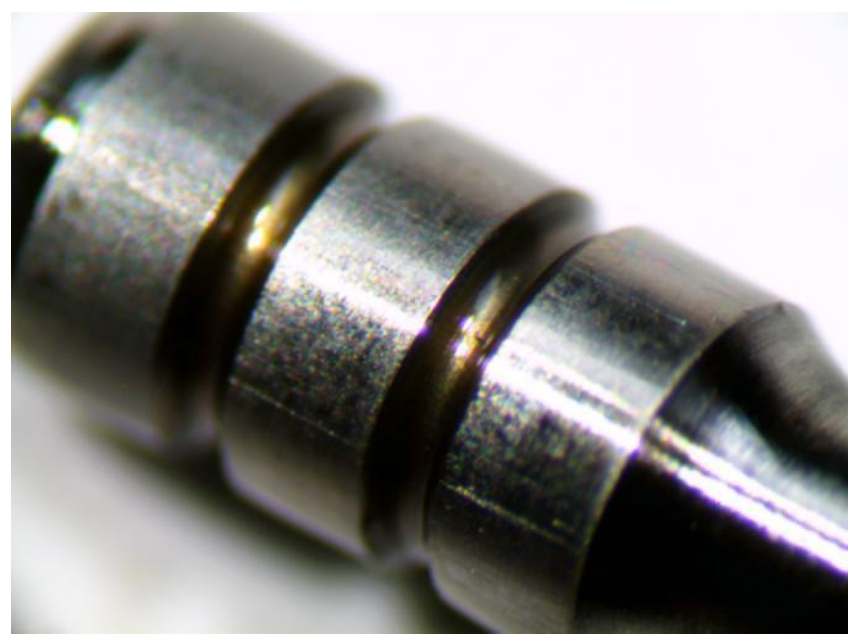

Fig. 5. Friction wear on the guide surface of the control valve

During the disassembly phase, it was found that the control valve does not fall out of the body seat under the influence of gravitational force, which confirmed the earlier conclusions. In the next step, the components were subjected to cleaning baths in ultrasonic baths and microscopic inspection under high magnification (Figs. 4 and 5). Due to the identified signs of wear, it was decided that the repair would be limited to the replacement of the valve assembly, plunger and barrel assembly (needle and sprayer) and the solenoid coil seals, which were additionally lubricated with 
light liquid petrolatum. Since the results of the preliminary test were within the limits specified by the manufacturer, no additional correction of the fuel metering was carried out by changing the length of the control pin. The fuel injector was assembled and mounted on the test bench for further testing.

\subsection{Main tests}

Tables 5 and 6 show the results of the main tests that were carried out after the fuel injector regeneration process.

Table 5. Results of the main tests on the Zapp CRU 2i stand

\begin{tabular}{|c|c|c|c|c|}
\hline \multicolumn{3}{|c|}{ Test type } & \multicolumn{2}{|c|}{ Result } \\
\hline \multirow{3}{*}{$\begin{array}{l}\text { Electric test, } \\
\text { eRLC }\end{array}$} & \multicolumn{2}{|c|}{ Coil resistance, $R_{c}[\Omega]$} & \multicolumn{2}{|c|}{$\begin{array}{c}{[0.2-0.6]} \\
\mathbf{0 . 4 2}\end{array}$} \\
\hline & \multicolumn{2}{|c|}{ Coil inductance, $L[\mu \mathrm{H}]$} & \multicolumn{2}{|c|}{$\begin{array}{c}{[60-110]} \\
84\end{array}$} \\
\hline & \multicolumn{2}{|c|}{ Frequency, f [Hz] } & \multicolumn{2}{|c|}{20} \\
\hline \multicolumn{3}{|c|}{$\begin{array}{l}\text { Reaction speed test, } \\
\text { RSP }[\mu \mathrm{s}]\end{array}$} & \multicolumn{2}{|c|}{$\begin{array}{c}{[300-495]} \\
432\end{array}$} \\
\hline \multicolumn{3}{|c|}{$\begin{array}{l}\text { Nozzle opening pressure test, } \\
\text { NOP [MPa] }\end{array}$} & \multicolumn{2}{|c|}{$\begin{array}{c}{[13-23]} \\
15\end{array}$} \\
\hline \multirow{2}{*}{\multicolumn{3}{|c|}{$\begin{array}{l}\text { Leak Test, LKT [MPa] } \\
140 \mathrm{MPa}, 120 \mathrm{~s}\end{array}$}} & $\begin{array}{l}\text { Injection } \\
\text { dosage }\end{array}$ & $\begin{array}{l}\text { Return } \\
\text { dosage }\end{array}$ \\
\hline & & & $\mathbf{0}$ & $\begin{array}{c}{[0-40]} \\
2.06\end{array}$ \\
\hline \multicolumn{5}{|c|}{$\begin{array}{c}\text { Injector Volume Metering, } \\
\text { IVM }\end{array}$} \\
\hline $\begin{array}{c}\text { Dose } \\
\text { number }\end{array}$ & $\begin{array}{l}\text { Injection } \\
\text { pressure, } \\
\text { p inj }_{\text {inPa }]}\end{array}$ & $\begin{array}{c}\text { Nozzle } \\
\text { opening times, } \\
t[\mu \mathrm{s}]\end{array}$ & \multicolumn{2}{|c|}{$\begin{array}{c}\text { Injection } \\
\text { dosage, } \\
\mathrm{d}\left[\mathrm{mm}^{3} / \mathrm{H}\right]\end{array}$} \\
\hline $1^{\prime \prime}$ & 40 & 462 & \multicolumn{2}{|c|}{$\begin{array}{c}{[1.18-7.91]} \\
\mathbf{4 . 5 8}\end{array}$} \\
\hline 2 & 80 & 600 & \multicolumn{2}{|c|}{$\begin{array}{c}{[14.43-31.35]} \\
\mathbf{2 2 . 1 4}\end{array}$} \\
\hline $3 "$ & 140 & 700 & \multicolumn{2}{|c|}{$\begin{array}{c}{[31.83-46.33]} \\
\mathbf{3 8 . 8 6}\end{array}$} \\
\hline $4 "$ & 23 & 573 & \multicolumn{2}{|c|}{$\begin{array}{l}{[0.30-5.55]} \\
\mathbf{2 . 9 1}\end{array}$} \\
\hline
\end{tabular}

The repair should be assessed positively as the factory settings have been restored. As a result, the resulting fuel delivery field $\mathrm{A}_{\mathrm{MT}}$ and the reference one $\mathrm{A}_{\mathrm{SI}}$ are comparable, as the difference between them was only $4.37 \%$. For this reason, in the graphic interpretation presented in Figure 6 , they practically overlap. In the absence of an injector malfunction, the vertices of both figures have a similar position, and the shifts characteristic for the preliminary test does not occur.

Table 6. Calculation of the resultant fuel metering field $\mathrm{A}_{\mathrm{MT}}$

\begin{tabular}{|c|c|c|c|c|}
\hline $\begin{array}{c}\text { Dose } \\
\text { number }\end{array}$ & $\mathrm{t}_{\mathrm{i}}$ & $\mathrm{d}_{\mathrm{i}}$ & $\mathrm{t}_{\mathrm{i}+1}-\mathrm{t}_{\mathrm{i}-1}$ & $\mathrm{~d}_{\mathrm{i}+1}-\mathrm{di}_{-1}$ \\
\hline $1^{\prime}$ & 462 & 4.58 & 27 & 19.23 \\
\hline 2 “ & 600 & 22.14 & 238 & 34.28 \\
\hline 3 “ & 700 & 38.86 & -27 & -19.23 \\
\hline 4 “ & 573 & 2.91 & -238 & -34.28 \\
\hline $1^{\prime \prime}$ & 462 & 4.58 & $\Sigma=0$ & $\Sigma=0$ \\
\hline \multicolumn{5}{|c|}{$\mathrm{A}_{\mathrm{MT}}$} \\
\hline \multicolumn{6}{|c|}{$\mathbf{1 8 2 5 . 5 9}=1 / 2 \mid(27 \cdot 4.58)+(238 \cdot 22.14)+(-27 \cdot 38.86)+(-238 \cdot 4.58)$} \\
\hline $\mathbf{1 8 2 5 . 5 9}=1 / 2 \mid(19.23 \cdot 462)+(34.28 \cdot 600)+(-19.23 \cdot 700)+(-34.28 \cdot 573)$ \\
\hline
\end{tabular}

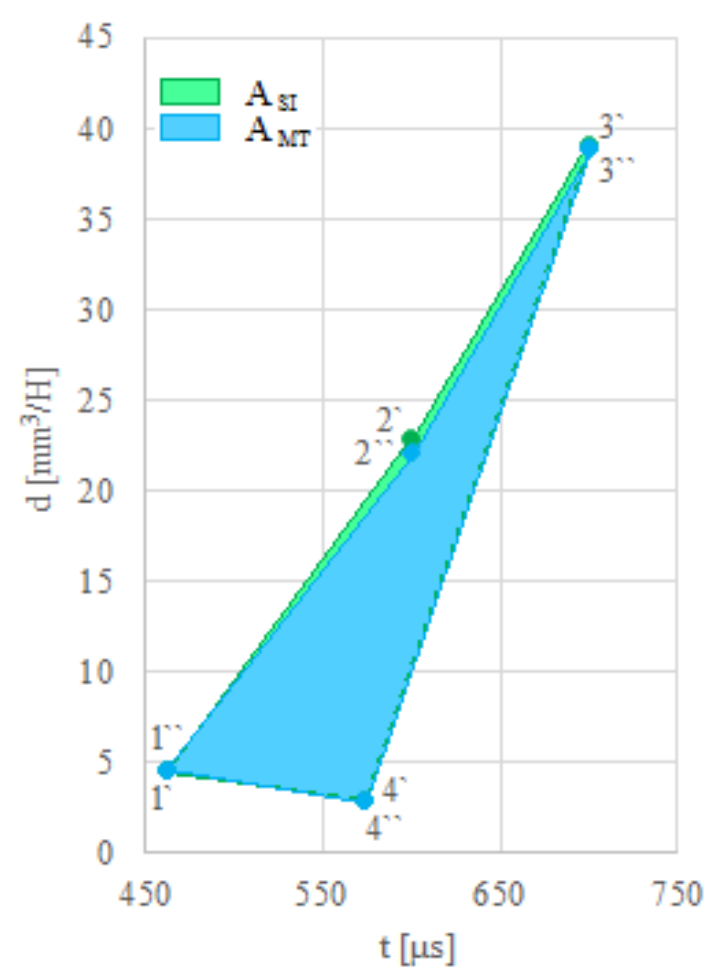

Fig. 6. Graphical interpretation of the main test results

\section{Conclusions}

The proposed methodology makes it possible to consider specific cases of failure of common rail fuel injectors that operate incorrectly despite meeting the required diagnostic criteria. As standard base points are taken into account in the calculations, its implementation does not require additional measurements on the test bench, which is an unquestionable advantage. There is also no need to modify the test bench software, as the analytical process was completely transferred to the popular spreadsheet environment. Algorithms created once in this way can be reused in the analysis of other cases and easily modified, adapting them to the procedures of a given manufacturer. In addition, in laboratory and repair shop conditions, graphic interpretation of the final results is not required, and the drawings presented in this paper are for illustrative purposes only.

It is also worth emphasising that the resulting fuel delivery fields should be treated purely hypothetically, as they do not reflect the actual fuel injection method at intermediate points, i.e. beyond the vertices of the generated figures. Nevertheless, their mathematical estimation allows for verification and assessment of the technical condition of the fuel injectors in problematic situations, as shown in a specific example. In view of the above, the presented methodology is an effective solution to the needs of the modern service market of fuel injection equipment, which have been signalled in recent years.

\section{Nomenclature}

A polygon surface area

$\mathrm{A}_{\mathrm{MT}}$ the resulting fuel delivery field in the main test

$\mathrm{A}_{\mathrm{PT}}$ the resulting fuel delivery field in the preliminary test
$\mathrm{A}_{\mathrm{SI}}$ the resulting fuel delivery field of the reference fuel injector

CDI Common Rail Direct Injection

d injection dosage 

eRLC Electric test
f frequency
IDID Internal Diesel Injector Deposit
IVM Injector Volume Metering
L coil inductance
LKT Leak Test
n number of vertices

NOP Nozzle Opening Pressure test

$\mathrm{p}_{\text {inj }} \quad$ Injection pressure

$\mathrm{R}_{\mathrm{c}} \quad$ coil resistance

RSP Reaction Speed test

$\mathrm{t} \quad$ nozzle opening times

$\mathrm{x}_{\mathrm{i}}, \mathrm{y}_{\mathrm{i}}$ coordinates of the $\mathrm{i}$-th vertex

\section{Bibliography}

[1] BALDIN, N. Estimating the volume of a convex body. Snapshots of modern mathematics from Oberwolfach. 2018, 15, 1-12. https://doi.org/10.14760/SNAP-2018-015-EN

[2] BERNDT, S., SCHÜMANN, U., SADLOWSKI, T. et al. Development of a laboratory test for the deposit forming tendency of diesel fuels. ATZ offhighway worldwide. 2018, 11, 50-55. https://doi.org/10.1007/s41321-018-0006-2

[3] BORZA, E.V., BĂLDEAN, D.L. Studiul posibilitătii de implementare a evaluării asistate de calculator în analiza injectoarelor common-rail Delphi. Stiintă Si Inginerie. 2018, 33, 33-35.

[4] BUSZ, W., WALASZYK, A. Optimize the testing process common rail fuel injectors. Combustion Engines. 2015, 162(3), 978-981.

[5] CORBETT, P.J., McINTOSH A.J.S., GEE, M. et al. Use of ionic liquids to minimize sodium induced internal diesel injector deposits (IDIDs). Molecular Systems Design \& Engineering. 2018, 3, 397-407.

https://doi.org/10.1039/C7ME00110J

[6] KARPIUK, W., BOR, W., SMOLEC, R. Possibilities of analysis of condition and repair of common-rail system injectors. Journal of KONES Powertrain and Transport. 2018, 23(4), 209-216. https://doi.org/10.5604/12314005.1217208

[7] KNEBA, Z., STRASZAK, P., JAKÓBCZYK, K. The effectiveness of fault detection in common rail injectors examination methods. Combustion Engines. 2017, 170(3), 49-56. https://doi.org/10.19206/ CE-2017-308

[8] OCHILBEK, R. A new approach (extra vertex) and generalization of Shoelace Algorithm usage in convex polygon (Point-in-Polygon). 14th International Conference on Electronics Computer and Computation (ICECCO). 2018, 206212. https://doi.org/10.1109/ICECCO.2018.8634725

[9] OLSZOWSKI, S., CHOJNACKI, T., OLSZOWSKI, T. Nieprawidłowa praca wtryskiwaczy common rail pomimo pozytywnego wyniku badania. Autobusy - Technika, Eksploatacja, Systemy Transportowe. 2017, 6, 1003-1007.

[10] OSIPOWICZ, T., ABRAMEK, K.F. Diagnosing methods common rail fuel injectors. Combustion Engines. 2017, 168(1), 56-61. https://doi.org/10.19206/CE-2017-109

[11] OSIPOWICZ, T., PRAJWOWSKI, K. Possibilities of research electromagnetic fuel injectors. Journal of KONES Powertrain and Transport. 2017, 24(3), 167-176. https://doi.org/10.5604/01.3001.0010.2928

[12] PUNOV, P. Research the fuel injection characteristics of a common-rail solenoid injector. Scientific conference on aeronautics, automotive and railway engineering and technologies - BulTrans2015. 2015, 153-158.

[13] PURE, R., DURRANI, S. Computing exact closed-form distance distributions in arbitrarily shaped polygons with arbitrary reference point. The Mathematica Journal. 2015, 17, 1-27. https://doi.org/doi:10.3888/tmj.17-6

[14] SCHÖPPE, D., ZÜLCH, S., HARDY, M. et al. Delphi Common Rail system with direct acting injector. MTZ Worldwide. 2008, 69, 32-38. https://doi.org/10.1007/BF03226918

[15] STĘPIEŃ, Z. A study of factors influencing the formation of harmful deposits in the diesel engine injectors. Eksploatacja i Niezawodność - Maintenance and Reliability. 2017, 19(3), 331-337. https://doi.org/10.17531/ein.2017.3.3

[16] STOECK, T. Methodology for Common Rail fuel injectors testing in case of non-typical faults. Diagnostyka. 2020, 21(2), 25-30. https://doi.org/10.29354/diag/122034

[17] STOECK, T. Simplification of the procedure for testing common rail fuel injectors. Combustion Engines. 2020, 180(1), 52-56. https://doi.org/10.19206/CE-2020-109

[18] STOECK, T., OSIPOWICZ, T., ABRAMEK, K.F. Methodology for the repair of Denso common rail solenoid injectors. Eksploatacja i Niezawodność - Maintenance and Reliability. 2014, 16(2), 270-275.

Tomasz Stoeck, DEng. - Department of Automotive
Engineering, West Pomeranian University of Tech-
nology in Szczecin, Poland.
e-mail: tstoeck@wp.pl 